Article for Australian Journal of Education

(final version, January 2006)

\title{
Vocational subject-making and the work of schools: a case- study
}

\section{Lyn Yates}

University of Melbourne

l.yates@unimelb.edu.au

Address for Correspondence:

Professor Lyn Yates

Faculty of Education

Alice Hoy Building

University of Melbourne

Vic 3010

Australia. 


\title{
Vocational subject-making and the work of schools: a case-study
}

\begin{abstract}
:
The rhetoric of the new vocationalism is about creating a new type of person: enterprising, flexible, lifelong learner, portfolio-oriented. The rhetoric of contemporary Australian government policy is that schools should be more vocational. This article focuses on schooling and a case-study of a site where two vocational 'dual accreditation' subjects are being taught. It argues (1) that different visions of schooling and vocational knowledge are evident at different levels of the system, but also between teachers involved in the same formal structure and between students within the same classes; (2) that the dual assessment regimes observed here embody not only different epistemologies, but different imputed identities of the learner-worker; and (3) that class and gender attributes matter but are not adequately acknowledged in the new agendas for school. The article illustrates ambiguities in what teachers and students are expected to do, and, in particular, a mixture of different ideas about what knowledge counts, and what attributes are valued within the school-based vocational subjects.
\end{abstract}

\section{Keywords:}

Vocational, schooling, knowledge, identity, assessment, case-study, 
The recent growth in VET in Schools... is part of a drive to prepare students in secondary schooling more effectively for employment... [V]ocational education in schools also forms part of a number of other reform agendas; for example, addressing broader concerns about the relevance and effectiveness of the senior secondary school curriculum, improving the transition from school to further education and training, and the promotion of lifelong learning. .

Australian House of Representatives Standing Committee on Education and Training Report, 2004: 7.1 (Australia 2004)

In Australia as in Europe, governments, training bodies, business councils and academic theorists are eager to scrutinize the changing economy, to identify the desirable attributes of the 'new worker' and to put in place (or critique) changes to education and training in terms of these 'new times'. A common theme in many of these discussions is that the new worker needs to acquire or display orientations and attributes that go beyond specific items of work-related knowledge and competencies. They need to be 'flexible', to be oriented to 'lifelong learning', to be able to present and communicate appropriately in different contexts; to maintain, update and present to the best advantage portfolios of their achievements; to be enterprising. Another common theme in these discussions is that institutional changes are required, that schools must learn to become more vocational, or vocational in a different way; and that rigid boundaries between institutions need to disappear, so that 'pathways' can become more flexible. But rhetorical calls for a re-construction of the worker and their training are one thing; the enactment and take-up of new practices is another.

Previous research has drawn attention to a range of problems and issues that are confronted when new policy rhetoric meets conflicting stakeholder interests and particular institutional and sector histories. Boreham (2002) for example, discusses the inherent conflict of interest between employers, governments and individual students in relation to training agendas and qualifications at school, and discusses how these play out differently in different structural conditions of governance of training in Germany as compared with the UK. Cho and Apple (1998) show that an attempt to instill new 'work subjectivity' through educational reform in Korea, achieved only token changes, due both to the inadequacy of implementation conditions (in terms of bringing teachers on 
side) and the resistance of students, attuned to other markers of social status. Williams (2005) reviews Australian reports and literature on new definitions of 'generic skills' in the 1990s and beyond, and points to the ambiguities and frequent contradictions as to whether these 'generic' competencies are seen as innate attributes of the person or are conceived as things that may be learned (and taught). Huddleston and Oh (2004) discuss some messiness and lack of empirical warrant in the hopes and agendas associated with 'work-related learning' in schooling policies in the UK. Shacklock (2000) argues that one of the directions most popular in recent Australian policy reform for schools, the fostering of 'enterprise', is popular precisely because it is a 'nebulous and contradictory' term, and some similar arguments are made by Pring (2004) in relation to the ubiqutous use of 'skills' in education reform policies in the UK, and by Hayward and Fernandez in reviewing shifts in key skills agendas (Hayward 2004; Hayward and Fernandez 2004).

This article draws on a case-study of two school-based 'dual accreditation' vocational classes in New South Wales ${ }^{1}$ studied as part of a larger ARC-funded project, Changing Work, Changing Workers, Changing Selves studying vocational pedagogy across different institution and industry types.(Chappell et.al. 2003b) The background of the project is the rhetoric and literature regarding the 'new worker'. In terms of new vocational skills and transformations of self, the project sought to study whether or in what ways capabilities such as 'communication', or 'enterprising self' or 'flexibility' are being enacted in programs today, and how they are or are not affected by local specificities. Across the different education sites, the project asks two types of questions about the developments:

- what is actually being enacted in classrooms now as 'knowledge' in these vocational subjects? and

- what identities about work and working knowledge are being constructed, affirmed, marginalised in the process?

This particular article draws on research related to schooling as a site. One interest here is to consider actual classroom practice in relation to the rhetoric by which the policies and reforms have been introduced; a second is to consider the actual classroom practices

\footnotetext{
${ }^{1}$ The move to extend vocational orientations and opportunities in school in Australia is a national one, but the school curriculum, assessment and teacher professional development are organized on a state basis, and both the form of the HSC certifications and the form in which vocational subjects are currently accredited is not uniform across states.
} 
against the burgeoning literature on new times, new knowledge, new forms of work and identity (for example, Cairney 2000; Garrick and Rhodes 2000; Gee 2000; Curtis and McKenzie 2001; Howse 2001; James 2002; OVAL 2003; Lumby 2004). Substantively, the article focuses on two aspects of vocationalism as pedagogy in the context of schooling: the different conceptions of the agenda being expressed by different players in this arena; and the driving force of assessment regimes, and the conflicting epistemologies and imputed worker positionings these embody. It deals in turn with three questions, all framing a dialogue between policy and literature on the one hand and the case study empirical data on the other (Yates 2003 elaborates methodological approach). The questions are, 1. In terms of 'new' and 'old' vocationalism: who speaks what language? 2. How do you combine two conflicting assessment regimes? and 3. Who is the worker imagined to be?

In this case-study, two vocational classes, one in Hospitality Operations and one in Information Technology, are being taught in the final year (year 12) of a NSW high school. The classes are both 'dual accreditation' subjects: students are assessed for Certificate II competencies within the Australian Qualifications Framework, a recognized assessment scheme for industrial awards. Students taking the subject can also take examinations in those subjects within the Higher School Certificate, and by doing so gain scores which will count towards their combined university entrance score (UAI). The subjects are recognized components of the year 12 course of study regardless of whether the student sits the HSC examination, and it is not mandatory that they do the latter. However only students taking the examination will receive a numerical score and be able to use the subject for university admission purposes.

\section{In terms of 'new' and 'old' vocationalism: who speaks what language?}

In 2002, the Australian government funded a national conference on 'VET in schools', run jointly by the Australian College of Education and the Enterprise Foundation. The funding stream itself bears tribute to the fashionableness of concerns about 'new vocationalism' and 'new work order' referred to in my introduction. But the papers and discussions at that conference signalled that what 'VET in schools' means and the issues it signals, is constructed differently by people positioned in different places in the schooling system.(Australian College of Educators 2002) For some, the issue is about developing greater vocational attributes, orientations and identity across all students. For 
others, the issue is about how accredited vocational subjects should be taught, and the problems in adequately teaching these (especially in relation to work placement). And for yet others, the issue of VET is about 'marginalized' or 'at risk' students, and special projects that can be put in place in partnership with industry to save these. The Australian parliamentary inquiry report into VET in schools (Learning to Work, Australia 2004) itself spends two out of its ten chapters discussing differences and conflicting agendas in relation to this arena.

Agendas about vocational learning in schools are messy because the new policy moves confront older constructions both about who vocational students in schools are and about what vocational knowledge is. Historically, 'vocational' in the context of secondary schools in Australia, was framed in a class-based differentiation of types of students and a mental-manual differentiation of types of knowledge. 'Vocational' subjects were particular courses of study for those students who do not do well in 'academic' subjects, forms of study where core subjects such as English and Mathematics will be modified and seen to be of lower standard, and where students taking the vocational subjects will proceed to jobs or apprenticeships and not to university. 'Vocational' teachers often were recruited differently to 'academic' teachers, with different courses of training and more restricted career opportunities. Vocational students in this conception were not all students but some students.

In terms of what vocational knowledge looks like, the contemporary forums and policy changes confront a second issue, the changing nature of jobs and of work. The various attempts to construct 'generic' skills and attributes is emblematic of the new problematic. (Curtis 2001; Hayward 2004; Hayward and Fernandez 2004; Williams in press). Policies and literature across a wide spectrum are concerned about the knowledge society, ongoing change, the belief that workers will be required to change jobs and learn new things in the course of their working lives. So the question of vocational curriculum for schools also elicits questions about whether 'working knowledge' today is about having particular skills for a particular workplace, or about learning a process of learning, or is about learning to be a certain type of person, with more generic abilities to present one's competencies to best advantage, and more general foundations in ongoing learning (Gee 1999; Beckett and Hager 2002; Chappell et.al. 2003a; Chappell et.al. 2003b). 
In the schooling component of the Changing Work, Changing Workers, Changing Selves project we interviewed education department personnel working in the VET in Schools directorate of the state education department, the principal of the school where the casestudies were located, the class teachers of the two subjects, and a group of students from each of the classes. We found that the rhetoric of the new vocationalism was much more apparent at the centre of the education bureaucracy than it was at the chalk-face. In the school, for the principal and students as well as the teachers, it is more short-term and industry-specific concerns that dominate.

Sociologically it is hardly surprising that the literature of the 'new' vocationalism, the talk of 'enterprise' and 'flexibility' and 'lifelong learning', is much more likely to be found among those who have the time and conditions to be reading, talking, going to conferences about the 'big picture'. The people in the policy and professional development units of the education department were the ones at home with these themes, and were producing a stream of manuals for schools, using the new terminology. When we attended a briefing by the people from this unit, they indicated their approval that we used the term 'vocational learning' rather than VET, and gave us a copy of a handbook they had produced and were hoping to distribute to all schools, which guided students to produce a portfolio of vocational accomplishments that they could use for later work purposes. This 'Work Skills Logbook’ for schools, we were told, is:

meant to provide a way for students to record what they are learning vis-a-vis work in all the contexts of the student's life. In documenting various activities in their lives and the sorts of competencies involved (for example, 'leadership'), the logbook trains students in how to explicitly link other parts of their life to work or job skills so they can show these in their CV and can articulate those links in a job interview.

(from notes from Department VET in Schools briefing, November 2002)

The orientation of the people employed in the VET Directorate within the education department was one of broadly 'vocationalising the curriculum' (which, of course, would also offer opportunities for greater prominence of their own particular unit within the labyrinth organizational structure of this particular large education bureaucracy). They saw their mission in terms of increasing the vocational orientation of all students (students in so-called 'academic' streams as well as those tagged 'vocational'), though 
in structural terms it was the VET teachers who were their professional development constituency. These curriculum developers emphasized the centrality of planning, portfolios, flexibility in the modern world. They talked of their frustration in getting selective academic schools to take their work seriously.

Irene $^{2}$ : in many ways it is those tertiary study students who most need to plan their career pathways because a lot of them drop out or else make other decisions.

Malcolm: The days of one career, even in law and medicine, are over and you're probably going to have to make a whole lot of transitions, so it's the planning process that enables them to "get the evidence"...

The curriculum developers (and policy-makers) then are the vanguard of certain new moves to vocationalize schools more broadly, but are also constrained by their association with an area that already has a history and given set of associations, and in which speaking from a 'vocational' unit carries less class-based prestige and power than those closely associated with high status subjects and universities. (It is probably the latter rather than the resistance to portfolios and career planning as such that was causing the unwillingness of higher status schools to engage with this unit.)

At the school level, the interview with the principal suggested that, in his view, vocationalism was taken up not because it was important for all students, but because it specifically benefited those students who had been losing out within a traditional academic hierarchy. He saw the VET area as being centrally about a different type of knowledge.

So rather than doing a watered down version of the traditional academic course, a student particularly in hospitality can demonstrate extremely high level of skills in hospitality and go and in the work placement be very highly regarded and go out into the workforce and through TAFE get an excellent job, whereas they may have left the HSC, the traditional HSC, at a school that didn't value those skills with a very low UAI and a very poor opinion of their own academic skills. But at least by participating in VET it enables those particular skills, the VET skills, to be recognised and acknowledged and rewarded.

\footnotetext{
${ }^{2}$ pseudonyms have been used.
} 
He also had promoted these particular programs for this school because it offered a niche opportunity for this school

In 1999 to 2000 an opportunity arose then. This was at a time when there [were] discussions in relation to the new HSC, when there was an intention from the Board of Studies to enable the vocation ... to strengthen the place for vocational courses within the curriculum and allow students to include those courses in their university admission. Now at this time [name of school] was very well placed because already we had established a very high reputation for courses such as hospitality and furnishings. Students were coming to [name of school] from other schools in the district that weren't able to offer them. An opportunity then arose to apply for Commonwealth funding from ANTA to apply for the establishment of a skills centre.

For the principal then, the 'new vocationalism' of policy-makers is a field of niche opportunity, but one that is taken up within more long-standing and binary conceptions of who vocational students are and what working knowledge looks like.

For the classroom teachers, too, there was little emphasis in their interviews or informal comments during classes about a need to prepare a new type of person, a person with a new awareness of their own skills (as in the work logbook portfolio conception), or a person for whom this would be just the first step on a continuum of 'life-long learning' (our observations and interviews here are discussed in more detail in (Tennant and Yates 2003, 2005). For the hospitality teacher, what was important was to produce students who had a real commitment to this particular industry (or, more specifically, to cooking), who had the technical skills for the entry level positions they would enter, and who would display these well to employers in their work placements:

But those who want to go into the industry are very quickly identified by um, the way they work. Okay, they are the ones that get in. In the theory maybe not so much, but in the practical, they are the ones that are really trying hard to hold the knife, to put the fingers in the right space, to get the proper product, to plate it up properly, okay. And they stand out. Already in my year 11 class I have 
identified three or four students who when I've, when they've just picked their work placement, I've directed into places.

For the IT teacher, the important thing was that those who wanted to get new skills alongside their academic studies could do so, and those who had skills already had the opportunity to display this to employers. In the interview with us, this teacher did talk some of the language of the 'new' vocationalism

I think school students need to learn communication skills because I think although they probably have the ability, and they probably do have good skills they don't always use them.[...] I mean they are mature in some ways but they are still their age, so I try to get them to sort of appreciate that there are other points of view besides their own so that when they are in situations, like conflict situations, instead of getting crushed or um taking things personally, they can sort of step back a bit and think about how to handle it, that's all I was trying to get through to them.

However when we observed the teacher actually teaching the 'communication' topic in class, the lesson was dominated by definitions drawn from old textbooks, with little attempt to relate this to students' actual workplace experiences. For this teacher, a central reality of students' workplace futures is that a high HSC score is important, and needs to be given priority in the way she teaches the course.

In our focus groups with students from the two classes we found a limited and mixed take-up of what it meant to be vocationally oriented. It was common for students to recognize the value of certification of skills:

It helps you in life. You get a certificate for doing it.

Hospitality student, female

...you can fall back onto it knowing that you still have a certificate and then, even if you don't want to be a chef, like the hospitality industry you get exempt from heaps of the stuff because you've done it at school

Hospitality student, female 
Well the other subjects I'm doing are different from this, so then if like say I don't want a career in those subjects I can fall back on this and I'll do the HSC course and um like the exam and also hopefully certificate 2, is it, yeah, and have that so I can show if I want to work in a restaurant or what ever. I can have that.

\section{Hospitality student, male}

I just wanted a certificate and the HSC

$$
\text { IT student, male }
$$

Just to show that I had some knowledge of computers, for future reference.

$$
\text { IT student, female }
$$

Oh I'm actually doing another certificate at TAFE, part-time at night, just to get knowledge.

\section{IT student, male.}

But the IT students in particular were less certain that they were learning anything of value. Many already had the hands-on skills for the level certificate they were undertaking, and they had little respect for what they referred to as 'theory', the answers they would be required to produce for the HSC examination. The hospitality students were enthusiastic about the hands-on elements of their course. But, apart from the implicit recognition of a portfolio self that accompanies the respect for certification, there was virtually no unsolicited mention of anything relating to generic skills or abilities as part of these students' sense of what they were gaining within these subjects.

\section{How do you combine two conflicting assessment regimes?}

The 'dual accreditation' systems under which the classes we observed were operating were (1) the Higher School Certificate, a written examination-based system that is associated with the school system, and that regulates entry to university by converting achievement in subjects studied into a common scale and a single university entrance score; and (2) the Australian Qualifications Framework Certificate II, an assessment regime that is recognized for industrial awards, that has been traditionally taught through TAFE or workplaces, that requires assessment places and assessors to be registered and accredited as Registered Training Organization by a system that has regard to recent and 
relevant industrial experience, quality of the equipment, etc. The AQF is a competencybased certificate in which assessors tick off a long list of competencies as they are achieved by students, and in which the assessment is not graded but marked as 'achieved' or 'not yet achieved'. HSC is designed to produce spread and hierarchy, to work as a selection filter. AQF is designed to assess competency and job level classification and pay. HSC presumes different intellectual areas of study can be conflated into a single hierarchy of academic potential for university through a single entry score (the UAI). AQF presumes that a certificate level measures readiness to take on a particular role in an industrial hierarchy. The teachers we observed were accredited assessors, but were being required to work out themselves how to combine these two forms of assessment. They did not have a textbook or single guide to follow. And in the two classes we observed, very different things were happening.

The hospitality teacher was explicit in her disapproval that formal traditional examinations had been introduced for her subject. She told us this several times; mentioned it to the principal in our presence, and told us that she and other teachers had written to the Education Department to protest when the examinations were extended. This teacher loved the food industry, loved being in restaurants, and her aim was, as far as possible, to replicate the training she had experienced in TAFE, and to simulate practices of industrial kitchens. She expected the students to dress in uniform, disciplined them in the manner of a boss or a head chef by yelling at them if they did the wrong thing, spent a lot of time preparing them for their work placement or talking about it afterwards, demonstrating concern and pride that her students would demonstrate the technical skills (of cutting, using equipment etc) as well as the entry-level personal skills (of punctuality, good appearance and obedience) that that workplace would want. She was proud of the fact that her subject took students who often had an unsuccessful past history in academic subjects, and got them involved and interested and working well. She was also proud of the fact that a number of students each year gained job offers as a result of their work placement. She emphasized the kitchen hierarchy, and that what these students needed to understand in the first instance was their place at the bottom of this. Her emphasis then was on creating an identity for her students as a worker in commercial kitchens, and that this involved technical skills and knowledge and attributes of conformity and obedience. There was no obvious reference to developing either 'enterprise' qualities, nor to futures involving 'lifelong learning'. Nor was there any 
sense that the intellectual hierarchies of HSC and assessment had any place in preparing to enter hospitality. The mode of teaching was by traditional demonstration and practice and review.

In terms of the generic skills issue (Curtis and McKenzie 2001; Hayward and Fernandez 2004; Pring 2004; Williams in press), this teacher seemed to see specific skills (how to dice vegetables, or plan a menu, or give things the right names) as something to be taught; but skills under the more generic label (communication for example) largely as something the students brought to the situation. For example, she often talked to us about the shortcomings of students from families that had limited experience of eating out. Those who would do well were the students, largely middle-class girls, who were skilled at presenting themselves appropriately in different contexts. This was not something that was taught in the curriculum. And for the teacher as well as the students, writing examination answers about communication was something quite unconnected with actual work capabilities..

By contrast, the IT teacher told us repeatedly that she felt a responsibility to prepare these students to do as well as possible on the HSC examination and she gave most of her teaching time to this. Like the hospitality teacher, she marked off competencies along the way, and, with some difficulty, arranged work placements that were required by the course. But her over-riding concern was what type of knowledge would students need to do well on the written examination. When we first saw the class, she was teaching a unit on communication, using, what I thought was rather dated material from an old psychology textbook (the poor teacher had been left to find her own suitable resources whereas many other HSC subjects in this state issued a standard authoritative textbook). She repeatedly told the students how important it was to use the right terminology, and to learn correct definitions. On one rare occasion when she asked students about their own experiences in the workplace, and whether they had an embarrassing situation they were required to handle, the students gave some good answers ('I apologized and said I'd do it straight away, which I did'), but the teacher did not take these up or comment further on them.

In my fieldnotes here I had written, "The interchange in this part of the lesson gave me the impression that the students were more practically experienced than the teacher, that 
she was not making enough of their knowledge.” (This teacher had not in fact worked in the IT industry, and many of the students did have part-time jobs using IT skills.) Later, when I looked at the HSC examination, I realized I was doing her an injustice. Examination questions were not related to any actual situated contexts, and doing well did actually require one to learn what the past approved answers would be, not just be able to conduct oneself well in the actual setting or even to know more generally the answer to the question.

This first example is taken from the HSC Hospitality examination:

Q. Why are chefs required to wear uniforms when preparing food?

- A To prevent damage to their clothes

- $\quad B$ To designate the chain of command in the kitchen

- C To promote a team spirit and foster good team morale

- $\quad D$ To protect themselves and protect food from contamination

For ease of marking, examinations begin with some fixed choice short-answer questions, followed by some shorter problems and then some longer essays. But the short answer questions suggest that learning to be a worker or understand the workplace is a single and factual intellectual exercise (like learning a mathematics formula; or learning which medicine to prescribe for a particular illness) rather than a situation that may be thought about and require understanding in multiple ways. To get the correct answer in the shortanswer situation necessarily requires attention to what the examiners have themselves defined as the correct answer. Arguably, in the question quoted above, all of the above are correct (for example, at one of our other sites, a private hotel training school, perspective B was repeatedly emphasized to the students), yet the HSC examiners' report back to teachers simply lists their correct answer (D) and does not find it necessary to explain why other answers were incorrect (such an explanation is given in the case of any questions considered contentious).

Getting a good score on an HSC examination requires learning a particular genre of response, conquering the 'invisible pedagogy'. A question in the IT HSC examination was phrased this way: 
As a member of the company's help desk you have received a phone call from a receptionist at one of the branch offices. The receptionist, who has a stand-alone computer, is unable to print documents. (a) Explain ONE software problem that may be causing the receptionist to be unable to print. ${ }^{3}$

The Examiners' Notes on the scoring of answers to this question reported:

Candidates failed to recognize 'explain' involved 'cause and effect'. A high percentage gave a 'cause' answer but very few extended their answer to include an effect.

The Examiners' Notes cited an example of an insufficient answer, one that gave 'cause' only, as this:

The printer's driver may not be functioning correctly or is not installed properly. In fact the question itself had already cited an effect 'causing the receptionist to be unable to print'. According to examiners however a proper answer had to spell this out in the manner of the following exemplar:

There is a problem with the printer driver. This means that the computer does not recognise the printer, and therefore cannot print.

So what is at stake here is understanding a particular genre of textual response. The teacher correctly understood that learning the rules of elaborated codes and the academic game was something she needed to be teaching..

In the hospitality and the IT classes then, quite different things were being emphasized as knowledge. For the hospitality students, knowledge was technical skills, discipline, knowing how to act appropriately as one who was on the most junior rung of the occupational hierarchy. What bosses would think was constantly emphasized. In the IT class, what HSC examiners would think was the repeated mantra. There was some skills teaching here, just as, in the hospitality class, students who wished to do the examination were set essays and other tasks that were part of that preparation, but the dominant emphasis in each case was marked and different from each other, and there was little integration of why both conceptions of knowledge might have a place in these vocational classes..

\footnotetext{
${ }^{3}$ The following examples are taken from the NSW Board of Studies 2001 Higher School Certificate Examinations in Hospitality Operations and in Information Technology, and the 2001 HSC Notes from the Examination Centre sent to teachers the following year about these examinations and the ways they were assessed.
} 
What was being done in the two classes was not just an arbitrary choice, but related to each teacher's own experience and position (the hospitality teacher was well established in the school hierarchy, financially able to resign if she got sick of it, felt sufficiently powerful to voice her criticisms of HSC or of other provisions very forcibly; the IT teacher was not a permanent teacher and had not worked as an IT worker (she had trained as a science teacher). It also related to the cohort of students in each class and the teachers' perceptions of this. In the hospitality class, fewer of the students were seen as 'good' students academically, and few intended to try to go to university. In the IT class, we were told repeatedly about what a strong class this was academically, and only one student did not intend to sit the HSC examination.

The different pedagogies evident in the two classes also reflected these teachers' own interests and identifications. The hospitality teacher was passionate about restaurants, and believed in TAFE training approaches of which she had had some experience. The IT teacher had come to do her degree through a circuitous route. She valued the opportunities of doing this, and that going to university had given her.

So institutional histories, cohort composition, and particular teacher life histories all impact on how assessment and curriculum policies are read and enacted. And what is equally evident in relation to the rhetoric of the new policies, is that the huge workload of trying to integrate two existing training and assessment structures left little time for these teachers to be creatively developing attributes that were not already signalled in those assessments: context specific or reflexive knowledge, for example; career planning; or being 'enterprising'.

\section{Who is the worker imagined to be?}

At the national VET in Schools conference I referred to earlier, there was some confusion about who and what was the target of the discussion: was it all students, and their need to be made more enterprising and vocationally self-conscious? was it the students on the 'vocational' (trade-based) training pathways and how they might be managed in a school context? was it those who were 'at risk' and for whom new environments and opportunities needed to be found? But an even more pervasive slippage is evident in the general policy, curriculum and assessment formation, in which vocational qualities and vocational learning are constructed as attributes or achievements 
of some abstracted learner-worker, with no regard to embodied and demographic differences of actual students, or to actual workplace hierarchies, prejudices and problems. The policies may refer to generic skills, or to nurturing students who are flexible, reliable, enterprising but these tropes stem from some idealized working world, and some non-embodied and non power-differentiated conception of the workplace. This was evident when interviewing teachers and hearing about other issues that were a necessary part of their own consideration of work placements, employability attributes and conduct in the workplace, but were almost entirely invisible in the policies and curriculum guides provided for them.

For example, the IT teacher was struggling to place all her class because she has a 'duty of care' to these under-age students, and has to take account of where to place young women in terms of the composition of the workplace, and the late travel that might be required. At the same time, it is clear when the hospitality teacher points out the students who have been popular and successful in their workplace and likely to be offered further work, that being an attractive young woman is one 'employability' characteristic. In both cases, being embodied as female rather than male is not irrelevant to work placement opportunities and success. And specific local work placement realities and work opportunities can be different from the knowledge and aims that are formally taught in the curriculum and assessment documents. Employer bodies argue for 'enterprise' skills; but the hospitality teacher's experience is that most industrial kitchens want unquestioning obedience rather than anything else from their most junior trainee. The students in the IT class could supply examples of how they had dealt with communication issues in their workplace; but the assessment, particularly in the form of the examination, is a-contextual. It requires abstracted answers rather than lived or creative ones.

While the hospitality class was attempting to train students to simulate being a worker, and to practice being an entry-level worker in their workplace; the HSC examination presumed a hypothetical worker who can assume any position in the hierarchy. In a single IT examination for example, some questions are of the type a lowly administrative assistant might have to deal with, ('list four formatting changes needed...'); some presume a help-desk type of role; and others again, presume positions further up the hierarchy: 
draft a memorandum to staff explaining the company's policy and procedures for minimising the risk of computer virus infection and transmission...

or

The extension of non-smoking areas is a recent development in the hospitality industry. With specific reference to current occupational health and safety legislation, analyse how this development impacts on the roles and responsibilities of employers and employees in a hospitality enterprise.

Of course the point of these latter questions within the examination is to produce hierarchy and spread, to assess intellectual ability and not to assess role identifications for an actual workplace. A function of a question that requires analytic, synthetic and reportage skills as compared with getting a definition or calculation correct is to discriminate those who will be awarded distinctions, who will be seen as worthy to proceed to university—and as likely to become managers.

In the focus groups and from the class observations, it was evident that it was the students most likely to proceed to university who were most self-consciously aware about the presumed new work environment-of the need to gather multiple qualifications along the way, to have 'fall-back' options that would allow them to be flexible, regroup, take advantage of other opportunities. By contrast, in the IT class, the male students who were already highly skilled in technical computing skills envisaged the future simply as a skills-based ongoing extension of their present experience in their part-time job. They see their future as continuing to learn new technical things as different 'fixing' issues arise, but do not think about a future where they may go on to different types of work, or about what type of knowledge they would need to do so.

\section{Concluding comments:}

This is a period of continuing change in relation to curriculum and institutional arrangements for schooling and a range of different initiatives have been and are being developed in different Australian states. The point of this single case-study in one state then was not to offer a definitive description of what happens in schools, but to use a close-up study of one situation to elicit some of the issues confronting schools, teachers, students, and vocational education policy-makers. The case-study reminds us of the different pressures and influences affecting people in different parts of the education 
system; of the continued centrality of assessment in shaping what will be emphasized and conveyed to students; and of the relevance of teachers' own life histories, and students' own embodied differences in the way the curriculum is enacted and its outcomes produced.

In terms of the project's overall interest in 'pedagogies of the new vocationalism', in the school site discussed here, the young people were positioned as people to be taught things and drilled rather than as learners who have knowledge and experience that can be brought to the classroom (though many of them worked in part-time jobs). 'Knowing that' (in the case of HSC) and 'knowing how' (in the case of AQF) is conveyed as more important that 'knowing how to go on learning'. What employers thought of a student in their work-placements was important to teachers, but teachers had limited means of selecting employers or asking for particular types of input from them; and they did not have a role in the formal assessment processes. For the students, embodied being and family enculturation were relevant to how different students fared in the classes and in the workplace, but were not the subject of attention in the curriculum. Where course documents portray the good worker as one who is enterprising and flexible; the teachers, drawing on their own experience with employers, see the good (entry-level) worker as one who is reliable and obedient. The HSC is represented in policy terms as testing knowledge and understanding and intellectual ability; the teachers see it as a technology that has its own local criteria of what 'right answers' are.

It might be that this is a study of a time of transition, one in which the value of bringing vocational subjects into the senior school has been recognized, but where assessment and curriculum materials and technologies have not yet been refined into a new accord; and where the literature on 'new times' and the discourses of the flexible lifelong learneroriented new worker have not yet strongly penetrated the pedagogical and assessment practices. But the study also shows why some of these rhetorical demands are not easily achieved: how historical binaries as well as 'new times' permeates ideas about where the vocational sits and who vocational students are - and indeed, what counts as assessable knowledge; how short-term and local has to be somehow put together with longer-term curriculum objectives for what schooling should achieve; how teachers bring what has been important to them to any new directives. These are characteristics and conditions of vocational subject-making (in both senses) in schools that are unlikely to disappear. 
But within this story too, there is a story of how the young people themselves are entering these subjects and what are they making of that. In this site, both teachers and students were extremely positive about the opportunities afforded by 'dual accreditation', as well as about the opportunities to study in these particular vocational areas as part of the school curriculum. They may have to struggle with different visions of what is needed to be a worker today, and different epistemological conceptions of what knowledge is and how it might be developed-but they know the value of certification and of keeping options open.

\section{Acknowledgement:}

I thank NSW DET for permission to carry out this research and in particular the principal, teachers, students and curriculum officers who generously gave briefings and interviews and who allowed us to observe their classrooms. This paper is drawn from an Australian Research Council funded Discovery project (2002-4), Changing Work, Changing Worker, Changing Selves: a study of pedagogies in the new vocationalism. The research team from the University of Technology Sydney comprised Clive Chappell, Nicky Solomon, Mark Tennant, Carolyn Williams and Lyn Yates. The paper draws in particular on aspects of research carried out by the author in conjunction with Mark Tennant and builds on an earlier joint paper, 'New Times, Old Times: Issues of Identity and Knowledge in the Schooling of VET' presented at SKOPE Conference Oxford, July 2003.

References

Australia, House of Representatives Standing Committee on Education and Training. (2004) Learning to Work. Report on the inquiry into vocational education in schools. (Canberra, Commonwealth of Australia).

Australian College of Educators. (2002) Learning in a Knowledge Society: the vocational dimension. Unicorn (special issue) 28(3).

Beckett, D. \& Hager, P. (2002) Life, work and learning: practice in postmodernity. London, Routledge. 
Boreham, N. (2002) Work process knowledge, curriculum control and the work-based route to vocational qualifications, British Journal of Educational Studies, 50 (2), 225-237.

Cairney, T. (2000) The knowledge based economy; a review of the literature. (Sydney, Board of Vocational Education and Training).

Chappell, C. (2003) Researching Vocational Education and Training - where to from here? Journal of Vocational Education and Training 55(1), 21-31.

Chappell, C., Rhodes, C., Solomon, N., Tennant, M. \& Yates, L. (2003a) Reconstructing the lifelong learner: pedagogy and identity in individual, organisational and social change. (London, Routledge).

Chappell, C., Solomon, N., Tennant, M. \& Yates, L. (2003b) Changing work, changing workers: pedagogies of the new vocationalism. Proceedings of the $3^{\text {rd }}$ International Conference of Researching Work and Learning, University of Tampere, Finland.

Cho, M. K. \& Apple, M.W (1998). Schooling, work and subjectivity. British Journal of Sociology of Education. 19(3), 269-290.

Curtis, D. \& McKenzie, P. (2001) Employability skills for Australian industry: literature review and framework development. Report to Business Council of Australia. (Melbourne, Australian Chamber of Commerce and Industry).

Garrick, J. \&. Rhodes, C. (Eds) (2000) Research and knowledge at work. (London, Routledge).

Gee, J. (1999). New people in new worlds: networks, the new capitalism and schools, in: B.Cope \& M. Kalantzis (Eds) Multiliteracies: literacy learning and the design of social futures. (London, Routledge), 43-68.

Gee, J. (2000) The new capitalism. What's new? Working Knowledge Conference, University of Technology Sydney, RAVL (Research on Adult and Vocational Learning Group), University of Technology Sydney.

Hayward, G. (2004) Foreword: a century of vocationalism, Oxford Review of Education 30(1), 1-11.

Hayward, G. \& Fernandez, R. M. (2004) From core skills to key skills: fast forward or back to the future? Oxford Review of Education 30(1), 117-136. 
Howse, G. (2001) VET under review: the challenges in Central Asia, European Journal of Education, 36(1), 35-43.

Huddleston, P. \& Oh, S-A. (2004) The magic roundabout: work-related learning within the 14-19 curriculum, Oxford Review of Education, 30(1), 83-103.

James, P. (2002) Discourses and practices of competency-based training: implications for worker and practitioner identities, International Journal of Lifelong Learning ,21(4), 369-391.

Lumby, J. M. W. (2004) Developing 14-19 education: meeting needs and improving choice. Journal of Education Policy, 18(5), 533-550.

OVAL (Organizational Vocational and Adult Learning Research Group). (2003) Vocational learning for the 21st century: issues for pedagogy. ANTA Discussion Paper No.1. (Sydney, OVAL Research).

Pring, R. (2004) The skills revolution, Oxford Review of Education, 30(1), 105-117.

Raffe, D., Howieson, C., Spours, K. \& Young, M. (1998) The unification of postcompulsory education: towards a conceptual framework, British Journal of Educational Studies, 46(2), 169-187.

Shacklock, G., Hattam, J. \& Smyth, J. (2000) Enterprise education and teachers' work: exploring the links, Journal of Education and Work, 13(1), 41-60.

Tennant, M. \& Yates, L. (2003) Issues of identity and knowledge in the schooling of VET (OVAL Report to ANTA). (Sydney, OVAL Research).

Tennant, M. \& Yates, L. (2005) Issues of identity and knowledge in the schooling of VET: a case study of lifelong learning, International Journal of Lifelong Learning, 24 (3), 213-225.

Williams, C. (2005) The discursive construction of the 'competent' learner-worker: from key competencies to 'employability skills’, Studies in Continuing Education, 27 (1), 33-49.

Yates, L. (2003) Interpretive claims and methodological warrant in small number qualitative longitudinal research, International Journal of Social Research Methods, 6(3), 223-232. 
Final and authorised version first published in the Australian Journal of Education in vol.50 no.3, published by the Australian Council for Educational Research. Copyright ( 2006 Australian Council for Educational Research. 


\section{University Library}

\section{- M M I E R R V A gateway to Melbourne's research publications}

Minerva Access is the Institutional Repository of The University of Melbourne

Author/s:

Yates, Lyn

Title:

Vocational subject-making and the work of schools: a case-study

Date:

2006-11

Citation:

Yates, L. (2006). Vocational subject-making and the work of schools: a case-study. Australian Journal of Education, 50(3), 281.

Publication Status:

Published

Persistent Link:

http://hdl.handle.net/11343/33556 